Research paper

\title{
Anaerobic co-digestion of grass and forbs - Influence of cattle manure or grass based inoculum
}

\author{
Wen-Feng Cong ${ }^{\mathrm{a}, *}$, Veronica Moset ${ }^{\mathrm{b}}$, Lu Feng ${ }^{\mathrm{b}}$, Henrik Bjarne Møller ${ }^{\mathrm{b}}$, Jørgen Eriksen ${ }^{\mathrm{a}}$ \\ a Department of Agroecology, Aarhus University, Blichers Allé 20, DK 8830, Tjele, Denmark \\ ${ }^{\mathrm{b}}$ Department of Engineering, Aarhus University, Blichers Allé 20, DK 8830, Tjele, Denmark
}

\section{A R T I C L E I N F O}

\section{Keywords:}

Anaerobic co-digestion

Biogas

Forbs

Inoculum source

Multi-species grassland

\begin{abstract}
A B S T R A C T
Anaerobic co-digestion of agricultural by-products or wastes with complementarity characteristics is commonly used to enhance methane yield. This study firstly explores the possibility of co-digesting grass and forb species (white clover, chicory and plantain) differing in nutrient composition in enhancing methane yield. This was examined with two inocula (a cattle manure-based inoculum and a grass-based inoculum) in a batch assay. Results showed that co-digesting grass and forbs synergistically enhanced methane yield potential on average by $31 \mathrm{~L} \mathrm{~kg}^{-1}$ volatile solids $(+11 \%)$ and reduced lag phase time by 0.8 day in the grass-based inoculum, but not in the cattle manure-based inoculum. Mixtures containing plantain showed more consistent synergistic effect than chicory. Synergistic effects were attributed to more balanced nutrient composition (especially C/N ratio) in grass-forb mixtures. We demonstrate that anaerobic co-digestion of grass and forbs is feasible for enhancing methane yield, which promotes the utilization of multi-species grasslands for bioenergy production.
\end{abstract}

\section{Introduction}

Biogas produced through anaerobic digestion of agricultural byproducts, wastes or energy crops plays an important role in providing renewable bioenergy $[1,2]$. Biogas production can be enhanced through mixing two or more substrates with complementary characteristics because the anaerobic co-digestion process facilitates a better nutritional balance (e.g. N) and/or decreases the probability of inhibition (e.g. ammonia), leading to improved efficiency of microorganisms involved in anaerobic digestion [3,4].

Animal manure is a commonly used substrate co-digested with agricultural residues and energy crops to enhance biogas production and improve fertiliser values of digestates $[5,6]$. That is because animal manure contains higher nutrient concentrations (e.g. N) can facilitate the degradation of nutrient-poor agricultural residues. However, the production and pre-storage of animal manure are often associated with high risks of environmental pollution, such as greenhouse gas emissions (e.g. methane) and nutrient losses (e.g. ammonia) [7,8]. Hence, search for alternative and sustainable feedstock to animal manure has been put on the research agenda.

There is an increasing interest in using grassland biomass for bioenergy production in Europe and North America [9,10]. Current studies have been mainly focusing on different grass species or varieties $[11,12]$. Yet, the reported biogas production from grass species is generally low and varies widely among various energy crops $[1,10]$, probably because grasses alone contain relatively lower and unbalanced nutrients.

Recent studies show that some deep-rooting forbs species (e.g. chicory) are rich in some macro- and micro-nutrients (potassium, sulphur, zinc and boron) due to their uptake from deeper soil layers [13], while legume species (e.g. white clover) are well known to be rich in nitrogen $(\mathrm{N})$ in plant tissues. These forbs have recently shown notable biogas yields $[14,15]$. Hence, co-digesting grass and forbs with complementary nutrient composition could have a higher probability of synergistically enhancing methane production (i.e. higher methane production in mixtures than the sum of methane production from individual species digested separately). In addition, this positive effect would be more likely to occur in nutrient-poor inoculums produced from grass species than nutrient-rich inoculums from animal manure. That is because grass-forb mixtures provide nutrient composition that is more balanced than with single species, thereby compensating the possible nutrient limitation for microbial growth in nutrient-poor inoculum.

This study is to examine (1) how co-digesting grass and forbs in different substrate composition influences methane production potential and other kinetic parameters either synergistically, antagonistically, or neutrally; and (2) whether these effects depend on inoculum source. Two sources of inocula were used: one was produced based on

\footnotetext{
* Corresponding author.

E-mail address: wenfeng.cong@agro.au.dk (W.-F. Cong).
} 
commonly used cattle manure and agricultural residues (hereafter called as "Manure inoculum"); the other was produced using organically managed grass ley ("Grass inoculum"). To address these questions, the batch test was employed because it enables us to characterise the kinetics of specific substrates under relative stable conditions (e.g. constant temperature) during anaerobic digestion. We hypothesized that synergistic effects occur in the Grass inoculum, but neutral effects occur in the Manure inoculum.

\section{Materials and methods}

\subsection{Substrates}

The substrates were from an existing field experiment established in spring 2014 at the Foulumgaard Experimental Station, Aarhus University, Denmark ( $\left.56^{\circ} 29^{\prime} 44 \mathrm{~N}, 9^{\circ} 34^{\prime} 3 \mathrm{E}\right)$. The experimental site had a mean annual rainfall of $770 \mathrm{~mm}$ and mean annual temperature of $7.7{ }^{\circ} \mathrm{C}$. The soil is classified as a Typical Hapludult with $6.4 \%$ clay, $8.5 \%$ silt, $44 \%$ fine sand, $39 \%$ coarse sand and $2 \%$ organic matter. The experiment followed organically managed practices and hence no fertiliser and pesticide were applied. To address the objectives of this study, pure stands of ryegrass (Lolium perenne L.), white clover (Trifolium repens L.), chicory (Cichorium intybus L.) and plantain (Plantago lanceolata L.) were selected. Each pure stand had two field replicates. Plants were harvested four times (May, July, August and October, respectively) by cutting the herbage at $7 \mathrm{~cm}$ stubble height using a Haldrup plot harvester (Haldrup C-85, Denmark). In August 2016, the harvested samples from each of the four pure stands were mixed across replicates. A subsample (ca. $1 \mathrm{~kg}$ ) was taken from each plant species, with unsown species removed. The subsample was then chopped into $1-2 \mathrm{~cm}$ size manually and stored at $-20^{\circ} \mathrm{C}$ until further analysis.

\subsection{Inoculum preparation}

Two sources of inocula were tested in this study, and prepared at the full-scale biogas plant in Research Centre Foulum, Aarhus University, Denmark. One is the Manure inoculum, collected from a full-scale thermophilic $1200 \mathrm{~m}^{3}$ reactor $\left(53{ }^{\circ} \mathrm{C}\right)$, and fed by $74 \%$ cattle manure, $8 \%$ deep litter, $8 \%$ maize, $8 \%$ grass and $2 \%$ silage for more than one year. This full-scale thermophilic digester was controlled at organic loading rate (OLR) of approximately $9 \mathrm{kgVS} \mathrm{m}^{-3} \mathrm{~d}^{-1}$ and HRT was 14 days. The other is the Grass inoculum, collected from a $100 \mathrm{~L}$ thermophilic pilot reactor which fed by $100 \%$ grass ley (tall fescue) for more than 3 months. The OLR and hydraulic retention time (HRT) for this

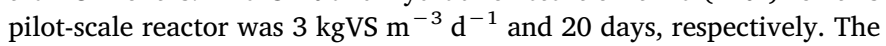
grass ley was established in spring in 2014 and managed with a two-cut strategy without fertiliser and pesticides. In October 2016, the grass ley was harvested and ensiled. The two inocula were filtered using manual sieve and stored for 2 weeks at $53{ }^{\circ} \mathrm{C}$ to minimise the residual biogas production and adapted them to batch conditions.

\subsection{Anaerobic batch experiment}

The methane potential of the substrates was analysed by a biomethane potential (BMP) test according to the approach described by Møller et al. [16]. Samples from the four species were used to construct 13 substrate compositions, comprising four single species, and nine mixed substrates varying with the forb species and mixture ratios of plant species on a basis of volatile solid (VS) (Table 1). Substrate composition represents biomass proportions of different species commonly observed in agricultural grasslands with different management practices.

The batch experiment was arranged in a factorial design with the 13 substrates and the two inocula as two factors. In addition, two blank controls with only the inoculum (Manure or Grass) were included. All the 28 treatments were examined in triplicate. The batch experiment
Table 1

Species composition of the 13 substrates used for the batch experiment.

\begin{tabular}{|c|c|c|c|c|}
\hline \multirow[t]{2}{*}{ Substrates } & \multicolumn{4}{|c|}{ Substrate composition ( $\%$ of VS) } \\
\hline & Ryegrass (G) & White clover (W) & Chicory (C) & Plantain (P) \\
\hline $100 \mathrm{G}$ & 100 & & & \\
\hline $100 \mathrm{~W}$ & & 100 & & \\
\hline $100 \mathrm{C}$ & & & 100 & \\
\hline $100 \mathrm{P}$ & & & & 100 \\
\hline 30G-50W-20C & 30 & 50 & 20 & \\
\hline 50G-30W-20C & 50 & 30 & 20 & \\
\hline 30G-30W-40C & 30 & 30 & 40 & \\
\hline 30G-50W-20P & 30 & 50 & & 20 \\
\hline 50G-30W-20P & 50 & 30 & & 20 \\
\hline 30G-30W-40P & 30 & 30 & & 40 \\
\hline $\begin{array}{l}\text { 30G-50W-10C- } \\
10 \mathrm{P}\end{array}$ & 30 & 50 & 10 & 10 \\
\hline $\begin{array}{l}\text { 50G-30W-10C- } \\
10 \mathrm{P}\end{array}$ & 50 & 30 & 10 & 10 \\
\hline $\begin{array}{l}\text { 30G-30W-20C- } \\
20 \mathrm{P}\end{array}$ & 30 & 30 & 20 & 20 \\
\hline
\end{tabular}

G, ryegrass; W, white clover; C, chicory; P, plantain.

was conducted at thermophilic conditions $\left(53 \pm 1{ }^{\circ} \mathrm{C}\right)$ for 96 days. In brief, $5 \mathrm{~g}$ VS (about 220-250 $\mathrm{g}$ ) of inoculum was added in each $500 \mathrm{~mL}$ infusion bottle, followed by adding $5 \mathrm{~g}$ (VS) substrate, resulting in a ratio of 1:1 ( $\mathrm{VS}_{\text {inoculum }}$ : $\left.\mathrm{VS}_{\text {substrate }}\right)$. The biogas volume was measured nine times at days $2,5,7,12,16,26,37,61,96$, respectively, by inserting a needle connected to a tube with inlet to a column filled with acidified water $(\mathrm{pH}<2)$ through the butyl rubber. The biogas produced was calculated by recording the volume of water displaced until the pressure between column and bottle headspace was equal. Biogas volume was normalised to standard conditions $\left(0^{\circ} \mathrm{C}\right.$ and $\left.1.013 \mathrm{bar}\right)$. Methane produced from each sample was calculated by multiplying biogas volume with methane fraction, and corrected by subtracting the volume of methane produced from the control.

To assess whether inhibition may occur in the batch experiment, the digestates of four single species in both inocula and two controls at the last measurement (Day 96) were characterised for its VS, $\mathrm{pH}$, volatile fatty acids (VFA) and total ammonia N (TAN).

\subsection{Analytical methods}

Subsamples of four plant species and two inocula were dried at $60{ }^{\circ} \mathrm{C}$ for $48 \mathrm{~h}$, and then ground $<0.5 \mathrm{~mm}$ (CT 193 Cyclotec $^{\mathrm{TM}}$ Sample Mill, Denmark). The total solid (TS) and VS were analysed using the procedure by APHA [17]. Total carbon (C) and N concentrations were analysed using a LECO CNS-1000 analyser (LECO Corp. St. Joseph, MI). The analysis of macro- and micro-nutrient concentrations was performed with ICP-MS (Inductively Couple Plasma-Mass Spectrometry) using a NexION 300 (PerkinElmer, USA). The acid detergent fibre (ADF), neutral detergent fibre (NDF) and acid detergent lignin (ADL) of plant samples were determined using the Van Soest method [18]. Cellulose was calculated as the difference between ADF and ADL, and hemicellulose as the difference between NDF and ADF. Crude protein (CP) was calculated by multiplying $\mathrm{N}$ concentration with 6.25 . All samples were analysed in duplicates, and the averaged values were presented.

Biogas composition was analysed by using gas chromatography (7890A, Agilent Technologies, USA) equipped with a thermal conductivity detector (TCD) and helium as the carrier gas. For digestates at the end of the experiment, $\mathrm{pH}$ value was measured using a Portamess $911 \mathrm{pH}$ meter (Knick, Berlin, Germany). Dissolved VFA were determined using a gas chromatograph (Agilent technologies, CA 95051, USA) equipped with a flame ionization detector (FID) and helium as the carrier gas. The TAN was determined using photometric kits (Spectroquant ${ }^{\circ}$ Test Kits, Merck, Germany). All samples were analysed 
Table 2

Chemical characteristics of four plant species.

\begin{tabular}{|c|c|c|c|c|c|}
\hline Parameters & Units & Ryegrass & White clover & Chicory & Plantain \\
\hline Total solid (TS) & $\%_{\mathrm{FM}}$ & $20.0 \pm 0.1$ & $15.7 \pm 0.2$ & $14.8 \pm 0.3$ & $18.3 \pm 0.1$ \\
\hline Volatile solid (VS) & $\%_{\mathrm{FM}}$ & $18.0 \pm 0.1$ & $14.0 \pm 0.1$ & $13.0 \pm 0.3$ & $16.5 \pm 0.1$ \\
\hline NDF & $\%_{\mathrm{vs}}$ & $53.2 \pm 0.6$ & $30.9 \pm 0.3$ & $39.6 \pm 0.5$ & $50.8 \pm 0.6$ \\
\hline $\mathrm{ADF}$ & $\%_{\mathrm{VS}}$ & $30.5 \pm 0.8$ & $23.0 \pm 0.4$ & $31.6 \pm 0.5$ & $39.1 \pm 0.6$ \\
\hline $\mathrm{ADL}$ & $\%_{\mathrm{vs}}$ & $2.42 \pm 0.09$ & $3.06 \pm 0.04$ & $2.06 \pm 0.14$ & $6.04 \pm 0.18$ \\
\hline Hemicellulose & $\%_{\mathrm{Vs}}$ & $22.7 \pm 0.22$ & $7.88 \pm 0.69$ & $7.92 \pm 0.00$ & $11.7 \pm 0.05$ \\
\hline Cellulose & $\%_{\mathrm{Vs}}$ & $28.1 \pm 0.7$ & $19.9 \pm 0.3$ & $29.6 \pm 0.4$ & $33.1 \pm 0.4$ \\
\hline Crude protein & $\%_{\mathrm{Vs}}$ & $13.3 \pm 0.2$ & $26.7 \pm 0.6$ & $12.2 \pm 0.7$ & $10.9 \pm 0.2$ \\
\hline Carbon (C) & $\%_{\mathrm{FM}}$ & $8.02 \pm 0.04$ & $6.23 \pm 0.02$ & $5.52 \pm 0.01$ & $7.29 \pm 0.02$ \\
\hline Nitrogen $(\mathrm{N})$ & $\%_{\mathrm{FM}}$ & $0.38 \pm 0.00$ & $0.60 \pm 0.02$ & $0.25 \pm 0.02$ & $0.29 \pm 0.01$ \\
\hline $\mathrm{C} / \mathrm{N}$ & / & $21.4 \pm 0.19$ & $10.5 \pm 0.24$ & $22.3 \pm 0.82$ & $25.4 \pm 0.72$ \\
\hline Phosphorus (P) & $\mathrm{g} \mathrm{kg}_{\mathrm{FM}}{ }^{-1}$ & $0.71 \pm 0.01$ & $0.42 \pm 0.01$ & $0.54 \pm 0.01$ & $0.57 \pm 0.00$ \\
\hline Potassium (K) & $\mathrm{g} \mathrm{kg}_{\mathrm{FM}}{ }^{-1}$ & $5.39 \pm 0.33$ & $3.79 \pm 0.23$ & $4.97 \pm 0.38$ & $4.32 \pm 0.29$ \\
\hline Calcium (Ca) & $\mathrm{g} \mathrm{kg}_{\mathrm{FM}}{ }^{-1}$ & $0.79 \pm 0.04$ & $1.89 \pm 0.02$ & $2.06 \pm 0.13$ & $1.78 \pm 0.15$ \\
\hline Magnesium (Mg) & $\mathrm{g} \mathrm{kg}_{\mathrm{FM}}{ }^{-1}$ & $0.28 \pm 0.01$ & $0.33 \pm 0.01$ & $0.27 \pm 0.04$ & $0.31 \pm 0.02$ \\
\hline Sulphur (S) & $\mathrm{g} \mathrm{kg}_{\mathrm{FM}}-1$ & $0.52 \pm 0.01$ & $0.34 \pm 0.02$ & $0.57 \pm 0.01$ & $0.59 \pm 0.04$ \\
\hline Sodium (Na) & $\mathrm{g} \mathrm{kg}_{\mathrm{FM}}^{-1}$ & $0.17 \pm 0.04$ & $0.15 \pm 0.05$ & $0.28 \pm 0.14$ & $0.08 \pm 0.01$ \\
\hline Iron $(\mathrm{Fe})$ & $\mathrm{mg} \mathrm{kg} \mathrm{FM}^{-1}$ & $35.86 \pm 2.70$ & $40.10 \pm 6.30$ & $30.30 \pm 2.60$ & $22.26 \pm 0.83$ \\
\hline Manganese (Mn) & $\mathrm{mg} \mathrm{kg}_{\mathrm{FM}}{ }^{-1}$ & $14.07 \pm 1.71$ & $8.22 \pm 0.49$ & $8.55 \pm 0.39$ & $4.14 \pm 0.17$ \\
\hline Boron (B) & $\mathrm{mg} \mathrm{kg}_{\mathrm{FM}}{ }^{-1}$ & $0.55 \pm 0.00$ & $2.46 \pm 0.07$ & $2.37 \pm 0.00$ & $1.81 \pm 0.00$ \\
\hline Zinc (Zn) & $\mathrm{mg} \mathrm{kg}_{\mathrm{FM}}{ }^{-1}$ & $4.13 \pm 0.10$ & $2.99 \pm 0.09$ & $4.60 \pm 0.33$ & $4.20 \pm 0.45$ \\
\hline Copper $(\mathrm{Cu})$ & $\mathrm{mg} \mathrm{kg}_{\mathrm{FM}}{ }^{-1}$ & $1.08 \pm 0.06$ & $1.05 \pm 0.01$ & $1.31 \pm 0.17$ & $1.12 \pm 0.03$ \\
\hline Molybdenum (Mo) & $\mathrm{mg} \mathrm{kg}_{\mathrm{FM}}{ }^{-1}$ & $0.26 \pm 0.04$ & $0.13 \pm 0.02$ & $0.11 \pm 0.01$ & $0.07 \pm 0.01$ \\
\hline Cobalt (Co) & $\mathrm{mg} \mathrm{kg}_{\mathrm{FM}}^{-1}$ & $0.03 \pm 0.00$ & $0.02 \pm 0.00$ & $0.02 \pm 0.00$ & $0.01 \pm 0.00$ \\
\hline Nickel (Ni) & $\mathrm{mg} \mathrm{kg}_{\mathrm{FM}}{ }^{-1}$ & $0.87 \pm 0.23$ & $0.42 \pm 0.13$ & $0.31 \pm 0.06$ & $0.16 \pm 0.02$ \\
\hline Selenium (Se) & $\mathrm{mg} \mathrm{kg} \mathrm{FM}^{-1}$ & $0.05 \pm 0.01$ & $0.03 \pm 0.01$ & $0.04 \pm 0.00$ & $0.05 \pm 0.00$ \\
\hline
\end{tabular}

' \pm ' Represents standard error of duplicates measurements.

based on one replicate.

\subsection{Calculation methods and statistical analysis}

\subsubsection{Modified gompertz model}

The methane yield production during 96 days was modelled by fitting the experimental data to the modified Gompertz equation (Eq. (1)):

$\mathrm{y}=\mathrm{B}_{0} \exp \left\{-\exp \left[\mu_{\mathrm{m}} \mathrm{e} / \mathrm{B}_{0}(\lambda-\mathrm{t})+1\right]\right\}$

where $y$ represents the cumulative methane yield $\left(\mathrm{L} \mathrm{kg}^{-1} \mathrm{VS}^{-1}\right)$ at time $(t)$ expressed in days; $\mathrm{B}_{0}$ is the cumulative methane yield $\left(\mathrm{L} \mathrm{kg}^{-1} \mathrm{VS}^{-1}\right.$ ) at the end of the batch (Day 96); $\mu_{m}$ is the maximal methane production rate $\left(\mathrm{L} \mathrm{kg}^{-1} \mathrm{VS}^{-1} \mathrm{~d}^{-1}\right)$, which is given by the slope of the line when methane is produced exponentially; e is the Euler's number, 2.718; $\lambda$ is the lag phase time (d) [19].

The first-order kinetic model, $y=\mathrm{B}_{0}[1-\exp (-k t)]$, was also used to fit the methane yield production. But given that the modified Gompertz equation generally provided a better goodness of fit than the first-order kinetic model, only the results derived from the modified Gompertz equation were reported.

The parameters $\mu_{m}$ and $\lambda$ were optimised by minimising the rootmean-squared error (RMSE). The coefficient of determination $\left(R^{2}\right)$ between predicted and observed methane yields was used to evaluate the precision of the model fit.

Two-way analysis of variance (ANOVA) was employed to analyse the effects of substrate composition and inoculum source on the parameters $\mathrm{B}_{0}, \mu_{m}$ and $\lambda$. In case of significant main factor effect, differences between treatments were tested using Tukey's post hoc test. Data were $\log$ transformed where necessary for statistical analysis to meet the assumptions of normality and heterogeneity.

\subsubsection{Estimation of co-digestion (synergistic or antagonistic) effect}

Two linear models (i.e. the full model and the additive model) were established to examine the co-digestion effect on parameters $\mathrm{B}_{0}, \mu_{m}$ and $\lambda$. The full model was constructed with all 13 substrate compositions, two inocula and their interactions as explanatory variables (Eq. (2)). The additive model consisted of only four plant species as explanatory variables, assuming no interactive effects of mixing species on these parameters in nine mixed substrates (Eq. (3)).

$$
\begin{aligned}
\mathrm{y}_{\text {full model }}= & \left(\beta_{\mathrm{G}} \mathrm{P}_{\mathrm{G}}+\beta_{\mathrm{W}} \mathrm{P}_{\mathrm{G}}+\beta_{\mathrm{C}} \mathrm{P}_{\mathrm{C}}+\beta_{\mathrm{P}} \mathrm{P}_{\mathrm{P}}+\beta_{\mathrm{j}} \mathrm{P}_{\mathrm{G}} \mathrm{P}_{\mathrm{w}} \mathrm{P}_{\mathrm{C}}+\delta_{\mathrm{k}} \mathrm{P}_{\mathrm{G}} \mathrm{P}_{\mathrm{W}} \mathrm{P}_{\mathrm{P}}\right. \\
& \left.+\delta_{1} \mathrm{P}_{\mathrm{G}} \mathrm{P}_{\mathrm{w}} \mathrm{P}_{\mathrm{C}} \mathrm{P}_{\mathrm{P}}\right) \gamma_{\mathrm{m}}+\varepsilon \\
\mathrm{y}_{\text {additive model }} & =\left(\beta_{\mathrm{G}} \mathrm{P}_{\mathrm{G}}+\beta_{\mathrm{W}} \mathrm{P}_{\mathrm{W}}+\beta_{\mathrm{C}} \mathrm{P}_{\mathrm{C}}+\beta_{\mathrm{P}} \mathrm{P}_{\mathrm{P}}\right) \gamma_{\mathrm{m}}+\varepsilon
\end{aligned}
$$

where coefficients $\beta_{i}$ estimate the performance of species $i$ (G: ryegrass, $\mathrm{W}$ : white clover, C: chicory, P: plantain). $\mathrm{P}_{i}$ is the proportion of species $i$ in a mixture and if $P_{i}=1, \beta_{i}$ measures the species' performance in a pure stand. Coefficients $\delta_{j}, \delta_{k}$ and $\delta_{l}$ measure the interactions between ryegrass, white clover with one forb (chicory or plantain), or with both forbs, respectively. Coefficients $\gamma_{m}$ estimate the effects of two inoculums (Manure and Grass).

The co-digestion effect was calculated as the difference between the outputs from the full model and the additive model. First, the $F$ test was conducted to test whether the co-digestion effect significantly occurred across the mixed substrates. Then, the matrix contrasts were defined for each of the nine mixed substrates to examine in which mixed substrate the co-digestion effect was significant. Taking the mixture 30G-50W20C for example, we subtracted the methane yield of this mixture estimated from Eq. (3) from that estimated from Eq. (2), and then examined whether the difference was significantly from zero. If the outcome is significantly larger than zero, the co-digestion effect is synergistic, otherwise the effect is antagonistic. Using the similar approach, we also examined whether the co-digestion effect was significantly different between the two inocula for a given mixed substrate. All analyses were performed using the $R$ software version 3.4.3.

\section{Results and discussion}

\subsection{Substrates and inoculum characteristics}

The main chemical characteristics of four plant species are summarised in Table 2. Ryegrass had the highest hemicellulose content, while plantain had the highest cellulose and lignin content, which was in line with our recent studies [20,21]. In contrast, white clover 
Table 3

Chemical characteristics of the Manure and Grass inocula.

\begin{tabular}{llll}
\hline Parameters & Units & Manure & Grass \\
\hline Total solid (TS) & $\%_{\mathrm{FM}}$ & $5.9 \pm 0.6$ & $3.1 \pm 0.01$ \\
Volatile solid (VS) & $\%_{\mathrm{FM}}$ & $4.8 \pm 0.5$ & $2.4 \pm 0.01$ \\
Phosphorus (P) & $\mathrm{g} \mathrm{kg}_{\mathrm{FM}}{ }^{-1}$ & 0.31 & 0.34 \\
Potassium (K) & $\mathrm{g} \mathrm{kg}_{\mathrm{FM}}{ }^{-1}$ & 1.43 & 2.18 \\
Calcium (Ca) & $\mathrm{g} \mathrm{kg}_{\mathrm{FM}}{ }^{-1}$ & 0.96 & 0.86 \\
Magnesium (Mg) & $\mathrm{g} \mathrm{kg}_{\mathrm{FM}}{ }^{-1}$ & 0.21 & 0.29 \\
Sulphur (S) & $\mathrm{g} \mathrm{kg}_{\mathrm{FM}}{ }^{-1}$ & 0.22 & 0.17 \\
Sodium (Na) & $\mathrm{g} \mathrm{kg}_{\mathrm{FM}}{ }^{-1}$ & 0.16 & 0.54 \\
Iron (Fe) & $\mathrm{mg} \mathrm{kg}_{\mathrm{FM}}{ }^{-1}$ & 76.03 & 67.90 \\
Manganese (Mn) & $\mathrm{mg} \mathrm{kg}_{\mathrm{FM}}{ }^{-1}$ & 15.84 & 10.94 \\
Boron (B) & $\mathrm{mg} \mathrm{kg}_{\mathrm{FM}}^{-1}$ & 0.82 & 0.77 \\
Zinc (Zn) & $\mathrm{mg} \mathrm{kg}_{\mathrm{FM}}{ }^{-1}$ & 10.70 & 6.41 \\
Copper (Cu) & $\mathrm{mg} \mathrm{kg}_{\mathrm{FM}}{ }^{-1}$ & 2.46 & 1.79 \\
Molybdenum (Mo) & $\mathrm{mg} \mathrm{kg}_{\mathrm{FM}}{ }^{-1}$ & 0.10 & 0.20 \\
Cobalt (Co) & $\mathrm{mg} \mathrm{kg}_{\mathrm{FM}}{ }^{-1}$ & 0.04 & 0.02 \\
Nickel (Ni) & $\mathrm{mg} \mathrm{kg}_{\mathrm{FM}}{ }^{-1}$ & 0.29 & 0.15 \\
Volatile fatty acids & $\mathrm{mg} \mathrm{l}^{-1}$ & $148 \pm 49$ & $159 \pm 86$ \\
Total ammonia N & $\mathrm{mg} \mathrm{l}^{-1}$ & $1147 \pm 111$ & $950 \pm 200$ \\
pH & $/$ & $7.6 \pm 0.1$ & $7.6 \pm 0.1$ \\
Methane in biogas & $\%$ & $55.2 \pm 1.5$ & $57.5 \pm 1.0$ \\
Specific methane yield & $1 \mathrm{CH}_{4} \mathrm{~kg}_{\mathrm{Vs}}{ }^{-1}$ & $234^{\mathrm{a}}$ & 126 \\
Volumetric biogas yield & $\mathrm{m}^{3} \mathrm{biogas} \mathrm{t}_{\mathrm{FM}}{ }^{-1}$ & 20.3 & 5.3 \\
\hline a & & & \\
\hline
\end{tabular}

' \pm ' Represents standard error of duplicates measurements.

a Methane and biogas yields in the Manure inoculum were calculated from the data of the cumulative biogas production of the whole period (62 days).

contained the lowest fibre composition. As expected, white clover contained larger $\mathrm{N}$ content and thus crude protein than grass and forb species, leading to a low $\mathrm{C} / \mathrm{N}$ ratio (10.5). Consistent with previous studies $[13,22]$, we observed that chicory generally held the highest concentrations of macro- and micro-nutrients among species because its deep roots facilitate larger uptake from deeper soil layers.

As expected, the Manure inoculum generally contained higher TS, VS and macro- and micro-nutrients than the Grass inoculum, except for potassium (K), magnesium ( $\mathrm{Mg}$ ) and sodium (Na) (Table 3). The Manure inoculum had slightly higher TAN, but similar VFA and pH as the Grass inoculum. Given higher concentrations of nutrients and VS, the Manure inoculum had higher biogas yield potential than the Grass inoculum.

\subsection{Methane yield potential, maximal production rate and lag phase}

Table 4 shows that the measured ultimate methane yield $\left(\mathrm{B}_{0}\right)$ after
96 days significantly differed between substrates $(P<0.001)$, but these differences strongly interacted with inoculum source $(P<0.001)$. In Manure inoculum, the highest $\mathrm{B}_{0}$ was found in single species of plantain $\left(343 \mathrm{~L} \mathrm{CH}_{4} \mathrm{~kg}^{-1} \mathrm{VS}\right)$ and white clover $\left(340 \mathrm{~L} \mathrm{CH}_{4}\right.$ $\mathrm{kg}^{-1} \mathrm{VS}$ ), being significantly higher than that in the mixed substrate with $50 \%$ ryegrass, $30 \%$ white clover, $10 \%$ chicory and $10 \%$ plantain (50G-30W-10C-10P). We observed higher $\mathrm{B}_{0}$ for plantain than the reported from Wahid et al. [15] (273 $\mathrm{L} \mathrm{CH}_{4} \mathrm{~kg}^{-1}$ VS). This could be due to approx. $10 \%$ higher cellulose and hemicellulose contents of plantain in this study. As for Grass inoculum, ryegrass produced the highest $\mathrm{B}_{0}$, with significantly higher yield than the two mixtures containing high amount of chicory (50G-30W-20C and 30G-30W-40C). Yet, the lowest $\mathrm{B}_{0}\left(226 \mathrm{~L} \mathrm{CH}_{4} \mathrm{~kg}^{-1} \mathrm{VS}\right)$ was observed in single species of white clover.

The modified Gompertz model was used to estimate the maximal methane production rate $\mu_{m}$ and lag phase time $\lambda$, two important parameters measuring the performance of anaerobic digestion. The model had an $R^{2}$ of $0.987 \pm 0.006(\mathrm{SD})$ across all cases, indicating a high precision of the model fit. Consistent with $\mathrm{B}_{0}$, white clover held the highest $\mu_{m}$ among all substrates in Manure inoculum, but the lowest one in Grass inoculum (Table 4). White clover had the highest $\lambda$ in both inocula, but with an especially long lag phase in Grass inoculum. In addition, the substrates containing white clover generally had lower $\mu_{m}$ and higher $\lambda$ in Grass inoculum than in Manure inoculum.

\subsection{Mechanisms related to low production performance of white clover in grass inoculum}

The low production performance of white clover in Grass inoculum seemed not related to micronutrient levels of white clover since it contained either the largest or the intermediate concentrations of $\mathrm{Fe}$, Mo, Co and Ni (Table 2) among four species, which are key micronutrients for methanogensis [23]. However, white clover had high protein content and low $\mathrm{C} / \mathrm{N}$ ratio (10.5), indicating that ammonia inhibition may occur during anaerobic co-digestion [3,24].

To test this, we measured $\mathrm{pH}$ and the concentrations of VFA and TAN of four single substrates in both inocula at the end of batch experiment. The results showed that $\mathrm{pH}$ ranged between 7.3 and 7.8, and VFA concentrations maintained at very low levels $\left(<80 \mathrm{mg} \mathrm{L}^{-1}\right)$ across substrates and two inocula (Table 5). The TAN concentrations of four substrates ranged from 1.01 to $1.47 \mathrm{~g} \mathrm{~L}^{-1}$ in Grass inoculum, which was lower than the reported inhibitory values from 1.7 to $14 \mathrm{~g} \mathrm{~L}^{-1}$ [24]. Moreover, the highest TAN concentration $\left(2.21 \mathrm{~g} \mathrm{~L}^{-1}\right)$ was observed in white clover digested in Manure inoculum. These results indicated that low production performance of white clover in Grass inoculum could

Table 4

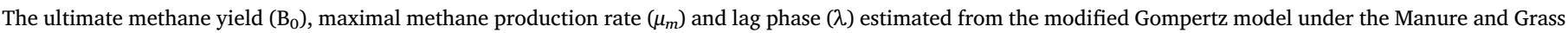
inocula.

\begin{tabular}{|c|c|c|c|c|c|c|c|c|}
\hline \multirow[t]{2}{*}{ Substrates } & \multicolumn{2}{|c|}{$\mathrm{B}_{0}\left(\mathrm{~L} \mathrm{~kg}^{-1} \mathrm{VS}\right)$} & \multicolumn{2}{|c|}{$\mu_{m}\left(\mathrm{~L} \mathrm{~kg}^{-1} \mathrm{VS} \mathrm{d}^{-1}\right)$} & \multicolumn{2}{|l|}{$\lambda(\mathrm{d})$} & \multicolumn{2}{|l|}{$R^{2}$} \\
\hline & Manure & Grass & Manure & Grass & Manure & Grass & Manure & Grass \\
\hline $100 \mathrm{G}$ & $311^{\mathrm{ab}}$ & $351^{\mathrm{a}}$ & $24.3^{\mathrm{ab}}$ & $26.8^{\mathrm{a}}$ & $0.12^{\mathrm{b}}$ & $0.00^{\mathrm{e}}$ & 0.987 & 0.980 \\
\hline $100 \mathrm{~W}$ & $340^{\mathrm{a}, *}$ & $226^{\mathrm{c}}$ & $28.1^{\mathrm{a}, *}$ & $8.0^{c}$ & $1.30^{\mathrm{a}, *}$ & $9.08^{\mathrm{a}}$ & 0.986 & 0.984 \\
\hline $100 \mathrm{C}$ & $291^{\mathrm{ab}}$ & $320^{\mathrm{ab}}$ & $17.6^{\mathrm{b}}$ & $16.1^{\mathrm{b}}$ & $0.09^{\mathrm{b}}$ & $0.00^{\mathrm{e}}$ & 0.984 & 0.960 \\
\hline $100 \mathrm{P}$ & $343^{\mathrm{a}}$ & $326^{\mathrm{ab}}$ & $23.9^{\mathrm{ab}, *}$ & $16.5^{\mathrm{b}}$ & $0.00^{\mathrm{b}}$ & $0.00^{\mathrm{e}}$ & 0.984 & 0.981 \\
\hline $30 G-50 W-20 C$ & $328^{\mathrm{ab}}$ & $318^{\mathrm{ab}}$ & $26.7^{\mathrm{a}, *}$ & $16.2^{\mathrm{b}}$ & $0.44^{\mathrm{b}, *}$ & $4.49^{b}$ & 0.983 & 0.991 \\
\hline $50 \mathrm{G}-30 \mathrm{~W}-20 \mathrm{C}$ & $304^{\mathrm{ab}}$ & $301^{b}$ & $21.6^{\mathrm{ab}, *}$ & $14.7^{\mathrm{b}}$ & $0.04^{\mathrm{b}, *}$ & $1.78^{\mathrm{d}}$ & 0.985 & 0.990 \\
\hline $30 G-30 W-40 C$ & $291^{\mathrm{ab}}$ & $287^{\mathrm{b}}$ & $20.3^{\mathrm{ab}, *}$ & $14.1^{\mathrm{b}}$ & $0.25^{\mathrm{b}, *}$ & $2.34^{\mathrm{c}}$ & 0.983 & 0.988 \\
\hline $30 G-50 W-20 P$ & $312^{\mathrm{ab}}$ & $304^{\mathrm{ab}}$ & $23.5^{\mathrm{ab}, *}$ & $16.0^{\mathrm{b}}$ & $0.07^{\mathrm{b}, *}$ & $3.75^{\mathrm{bc}}$ & 0.983 & 0.993 \\
\hline 50G-30W-20P & $326^{\mathrm{ab}}$ & $333^{\mathrm{ab}}$ & $24.6^{\mathrm{ab}}$ & $19.5^{\mathrm{b}}$ & $0.00^{\mathrm{b}, *}$ & $1.98^{\mathrm{d}}$ & 0.983 & 0.984 \\
\hline $30 G-30 W-40 P$ & $324^{\mathrm{ab}}$ & $332^{\mathrm{ab}}$ & $24.4^{\mathrm{ab}}$ & $18.4^{\mathrm{b}}$ & $0.00^{\mathrm{b}, *}$ & $1.29^{\mathrm{d}}$ & 0.983 & 0.982 \\
\hline 30G-50W-10C-10P & $303^{\mathrm{ab}}$ & $310^{\mathrm{ab}}$ & $23.1^{\mathrm{ab}, *}$ & $15.7^{\mathrm{b}}$ & $0.43^{\mathrm{b}, *}$ & $4.54^{\mathrm{b}}$ & 0.983 & 0.992 \\
\hline 50G-30W-10C-10P & $272^{\mathrm{b}, *}$ & $307^{\mathrm{ab}}$ & $18.6^{\mathrm{b}}$ & $16.5^{\mathrm{b}}$ & $0.22^{\mathrm{b}, *}$ & $1.81^{\mathrm{d}}$ & 0.985 & 0.988 \\
\hline $30 \mathrm{G}-30 \mathrm{~W}-20 \mathrm{C}-20 \mathrm{P}$ & $323^{\mathrm{ab}}$ & $335^{\mathrm{ab}}$ & $23.2^{\mathrm{ab}}$ & $19.2^{\mathrm{b}}$ & $0.03^{\mathrm{b}, *}$ & $2.16^{\mathrm{c}}$ & 0.984 & 0.985 \\
\hline
\end{tabular}

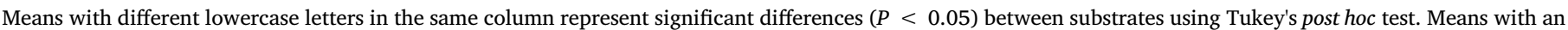

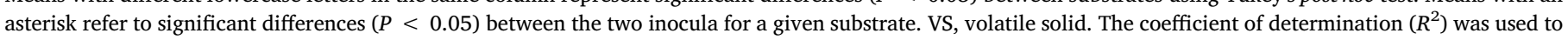
measure the goodness of a fit of the model. Abbreviations can be referred to Table 1 . 
Table 5

Chemical characterization of digestates of four single species under the Manure and Grass inocula at the end of the batch experiment (Day 96).

\begin{tabular}{llllll}
\hline Inocula & Substrates & $\begin{array}{l}\text { Volatile solid } \\
\left(\mathrm{VS}, \%_{\mathrm{FM}}\right)\end{array}$ & $\mathrm{pH}$ & $\begin{array}{l}\text { Volatile fatty } \\
\text { acids (VFA, mg } \\
\mathrm{L}^{-1} \text { ) }\end{array}$ & $\begin{array}{l}\text { Total ammonia N } \\
\text { (TAN, g L }\end{array}$ \\
\hline \multirow{2}{*}{ Manure }
\end{tabular}

${ }^{\text {a }} \mathrm{CK}$ refers to the corresponding inoculum without added substrate. Abbreviations can be referred to Table 1.

not be attributed to inhibition due to reduced $\mathrm{pH}$, or accumulation of ammonia or fatty acids.

We further found that low methane yield of white clover in Grass inoculum were from both its low biogas yield and methane fraction, especially in the first 16 days (Fig. 1b, d). This suggests that microorganisms in the grass-based inoculum did not adapt to white clover with low $\mathrm{C} / \mathrm{N}$ ratio in the beginning probably because the Grass inoculum was previously solely fed on grass hay with higher $\mathrm{C} / \mathrm{N}$ ratio. Such explanation was further supported by consistently high biogas yield and stable methane fraction of ryegrass digested in Grass inoculum throughout the digestion period (Fig. 1b, d). Interestingly, both biogas yield and methane fraction substantially increased in the following 10 days, suggesting an improved microbial adaptation over time. In addition, we found that methane fraction of white clover went up to $80 \%$ at day 26 , but stabilised at $60 \%$ at day 37 . This suggests that both acetotrophic and hydrogenotrophic methanogens have jointly contributed to methane production during this period [25].

Nevertheless, we did not observe improved ultimate methane yield of white clover in Grass inoculum (Table 4), which was confirmed by the highest VS remained after 96 days (Table 5 ). We further estimated $\mathrm{N}$ mineralisation rate of white clover by calculating the relative proportion of increased TAN concentrations during digestion in white clover $\mathrm{N}$ and assuming $1 \%$ loss of ammonia during gas sampling. We found only $55 \% \mathrm{~N}$ from white clover was mineralised in Grass inoculum, but up to 95\% in Manure inoculum. These results indicate a limited ability of the microbial community in adapting to substrates with different characteristics in batch conditions. This is further supported by recent studies showing that initial microbial community structure is crucial for determining ultimate methane production $[26,27]$. A number of studies have shown that microbial community structure sourced from different
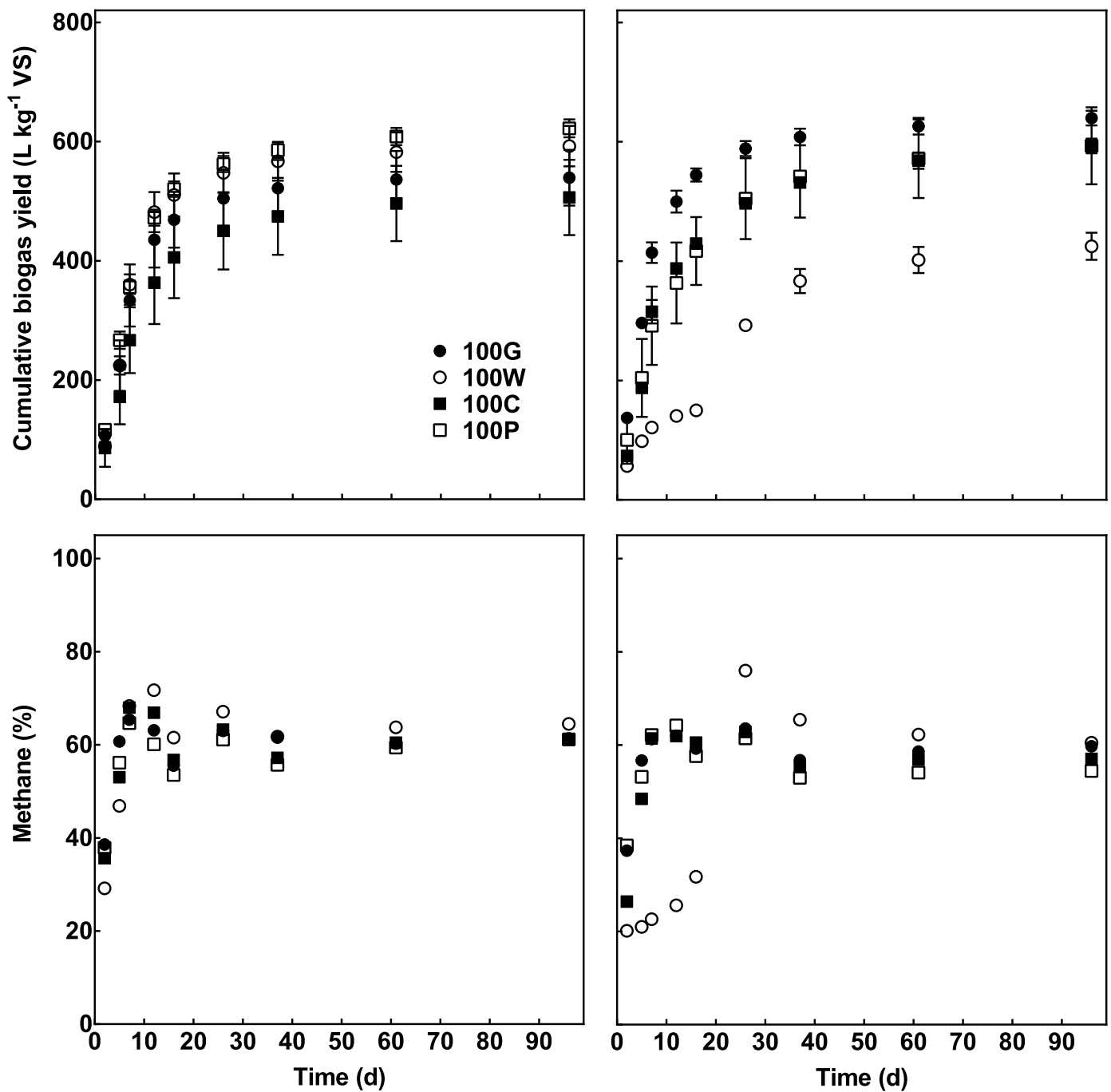

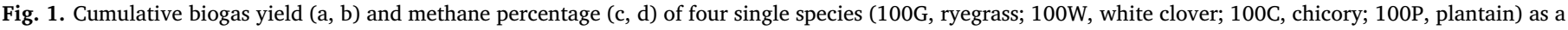
function of time from the two inocula (Manure: a, c; Grass: b, d). 

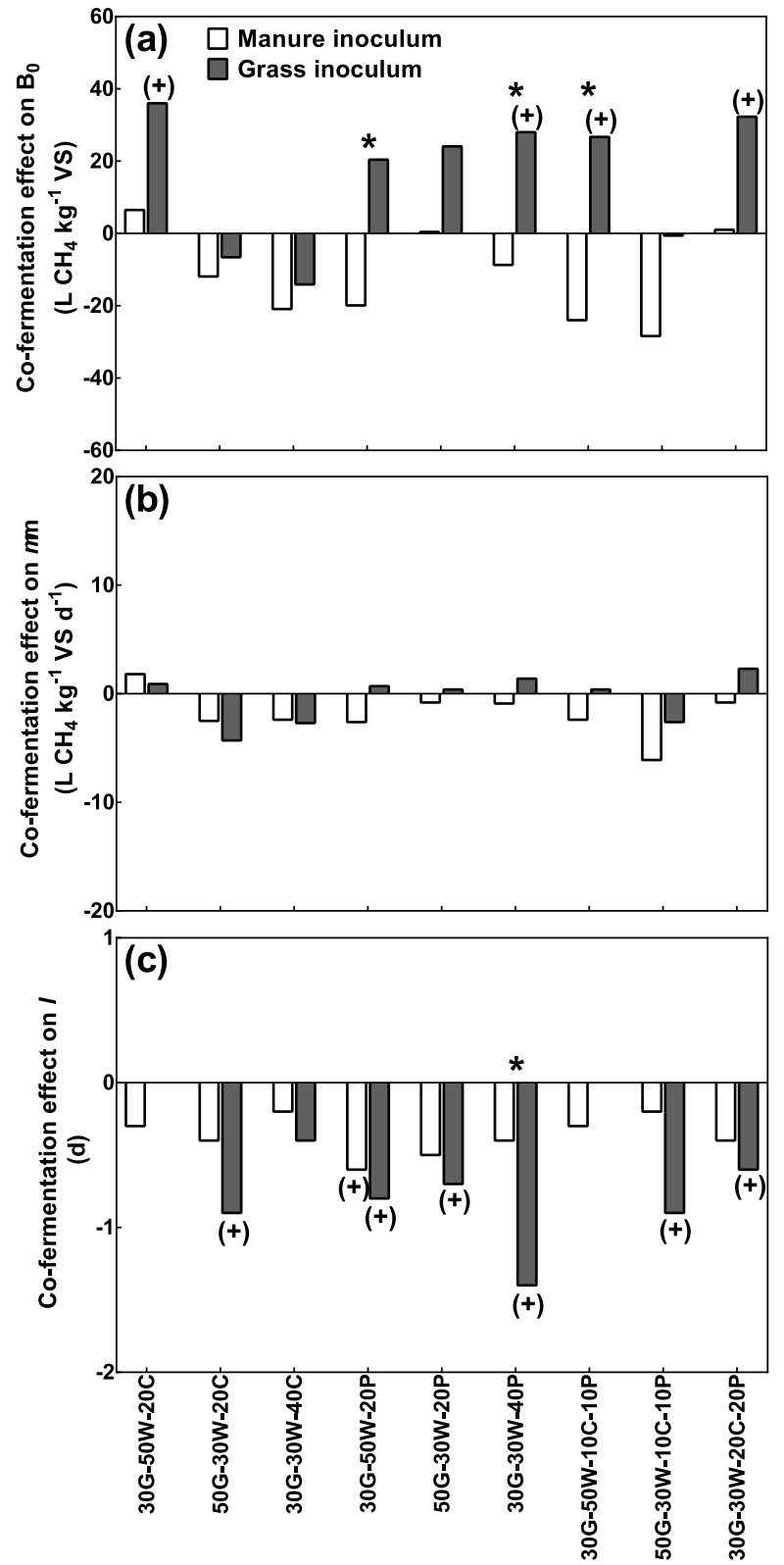

Fig. 2. The synergistic and antagonistic effect on ultimate methane yield $B_{0}(a)$, maximal methane production rate $\mu_{m}$ (b) and the lag phase $\lambda$ (c) in nine mixed substrates under two inocula (Manure, open column; Grass, filled column). The significant synergistic effects $(P<0.05)$ were indicated by $(+)$. Asterisk $(*)$ referred to significant difference in the co-digestion effect between the two inocula in a given mixed substrate. Abbreviations can be referred to Table 1.

inoculums initially differed but became similar in a continuous digester over time possibly due to a gradual acclimation to a given substrate [26]. Nevertheless, it is still unclear whether the degree of microbial acclimation varies with substrates or depends on initial microbial community. Further work would be relevant to explore whether and to what degree methane yield of white clover digested in the Grass inoculum can be improved via co-digestion with ryegrass in continuous reactors. Collectively, these results suggest low methane yield of white clover is unlikely due to inhibition, but probably because the initial microbial community in the Grass inoculum had a limited ability in digesting white clover.

\subsection{Synergistic and antagonistic interactions in grass-forb mixtures}

In line with our hypothesis, we found that co-digesting grass and forbs significantly enhanced methane yield potential $B_{0}$ in Grass inoculum in four of nine substrates (Fig. 2a). This enhancement was on average by $31 \mathrm{~L} \mathrm{CH}_{4} \mathrm{~kg}^{-1} \mathrm{VS}(+11 \%)$. In addition, co-digesting grass and forbs did not significantly influence maximal methane production rate $\mu_{m}$ (Fig. 2b), but significantly shortened the lag phase time $\lambda$ by 0.8 days in six of nine substrates (Fig. 2c). As expected, synergistic effects did not occur in Manure inoculum across all substrates. Certain mixed substrates tended to show an antagonistic effect on $\mathrm{B}_{0}$, but not statistically significant.

Improved production potential of grass-forb mixtures in Grass inoculum was probably because fermentative microorganisms had a better adaptation to grass-forb mixtures containing more balanced composition (especially $\mathrm{C} / \mathrm{N}$ ratio) than single species of white clover. Such mechanism has often been proposed to explain the synergistic effects occurring in co-digesting slaughterhouse wastes or sewage sludge with agricultural wastes such as animal manure and crop residues $[3,4]$. These findings imply that co-digesting multiple grassland species with complementary characteristics is an effective way to avoid low biogas production occurring in mono-digestion of single species.

Our results showed that the occurrence of synergistic effects appeared to depend on substrate composition, with higher frequency happening in mixtures containing plantain than chicory. This could be because plantain contained higher $\mathrm{C} / \mathrm{N}$ ratio and fibre composition than chicory (Table 2). Consequently, mixing plantain with white clover characterised by low $\mathrm{C} / \mathrm{N}$ ratio and fibre content provided a more balanced nutrient composition to facilitate methane production. Yet, we also observed a significant synergistic effect in the chicory-containing mixture (30G-50W-20C), suggesting that complex interactions among grass, white clover and chicory may function. Recent work has employed the simplex-centroid mixture design (SCMD) to examine the role of substrate combinations in contributing to methane production [28-30]. However, our experiment design did not rigidly follow up the SCMD approach (e.g. lack of two-species combination), which refrained us from performing further analysis for possible mechanisms. Further work may carefully follow this approach or more sophisticated approach such as artificial neural network to unravel which species combinations could lead to the synergistic effects, and to design the optimal mixture ratios for maximal methane production.

Furthermore, these results were based on one cutting strategy (fourcut strategy) in the batch mode. Our recent work showed that cutting frequency influenced fibre and nutrient composition of grass-forb mixtures and thus affected biogas yields in continuous stirred tank reactors [14]. It is worthwhile to explore whether such synergistic effect is subjected to cutting strategy and continuous mode.

\subsection{Grass-forb mixtures as alternative bioenergy feedstock}

We found that ryegrass, as a commonly used feedstock for bioenergy production, had the highest performance in terms of ultimate methane yield, maximum methane production rate and lag phase when inoculated with Grass inoculum (Table 4). However, the ryegrass-dominated grasslands are often associated with large input of mineral fertilisers, thus at the expense of high energy consumption and negative environmental impacts (Taube et al., 2014). Adding legumes (e.g. white clover) and non-leguminous forbs (e.g. plantain) to the ryegrassdominated grasslands has been recently found to deliver multiple ecosystem services, such as providing high and stable biomass feedstock for sustainable vehicle fuels [31], increasing nutritive value for livestock [20] and enhancing pollinations for arable crops [32]. Our results showed that co-digesting these forbs (white clover, chicory and plantain) with ryegrass maintained high methane yield potential as ryegrass digested alone over a wide range of substrate ratios in Manure inoculum and largely in Grass inoculum (Table 4). Hence, this finding could furthermore contribute to promoting the use of forb-based multispecies grasslands in enhancing ecosystem multifunctionality of agricultural grasslands. 


\section{Conclusions}

This study demonstrates that co-digesting grass and forbs synergistically enhanced methane yield potential and reduced lag phase time in a grass-based inoculum, but not in a cattle manure-based inoculum. These synergistic effects occurred more often in mixtures containing plantain than chicory. Synergistic effects were probably because grassforb mixtures provided a more balanced $\mathrm{C} / \mathrm{N}$ ratio and fibre composition that facilitated the growth of initial microbial community in the grass-based inoculum. Furthermore, mixing forbs with grass in a wide range of substrate ratios maintained as high specific methane yield as commonly used grass from pure stands, providing alternative grassland feedstock for bioenergy production.

\section{Declarations of interest}

None.

\section{Acknowledgements}

This work was supported by the Green Development and Demonstration Program 'MultiPlant' project [grant number 34009-130678] and coordinated by the International Centre for Research in Organic Food Systems. The authors gratefully acknowledge the technical assistance of the staff at Foulumgaard Experimental Station, and thank Radziah Wahid for earlier discussions and Rodrigo Labouriau for statistical advice.

\section{Appendix A. Supplementary data}

Supplementary data to this article can be found online at https:// doi.org/10.1016/j.biombioe.2018.09.009.

\section{References}

[1] T. Amon, B. Amon, V. Kryvoruchko, A. Machmüller, K. Hopfner-Sixt, V. Bodiroza, R. Hrbek, J. Friedel, E. Pötsch, H. Wagentristl, M. Schreiner, W. Zollitsch, Methane production through anaerobic digestion of various energy crops grown in sustainable crop rotations, Bioresour. Technol. 98 (17) (2007) 3204-3212.

[2] P.A. Gerin, F. Vliegen, J.-M. Jossart, Energy and $\mathrm{CO}_{2}$ balance of maize and grass as energy crops for anaerobic digestion, Bioresour. Technol. 99 (7) (2008) 2620-2627.

[3] J. Mata-Alvarez, J. Dosta, S. Macé, S. Astals, Codigestion of solid wastes: a review of its uses and perspectives including modeling, Crit. Rev. Biotechnol. 31 (2) (2011) 99-111.

[4] J. Mata-Alvarez, J. Dosta, M.S. Romero-Güiza, X. Fonoll, M. Peces, S. Astals, A critical review on anaerobic co-digestion achievements between 2010 and 2013, Renew. Sustain. Energy Rev. 36 (2014) 412-427.

[5] J.B. Holm-Nielsen, T. Al Seadi, P. Oleskowicz-Popiel, The future of anaerobic digestion and biogas utilization, Bioresour. Technol. 100 (22) (2009) 5478-5484.

[6] K. Möller, T. Müller, Effects of anaerobic digestion on digestate nutrient availability and crop growth: a review, Eng. Life Sci. 12 (3) (2012) 242-257.

[7] K. Möller, Effects of anaerobic digestion on soil carbon and nitrogen turnover, N emissions, and soil biological activity, A review, Agron. Sustain. Dev. 35 (3) (2015) $1021-1041$.

[8] S. Sommer, S. Petersen, H. Møller, Algorithms for calculating methane and nitrous oxide emissions from manure management, Nutrient Cycl. Agroecosyst. 69 (2) (2004) 143-154.

[9] S.B. McLaughlin, D.G. de la Torre Ugarte, C.T. Garten, L.R. Lynd, M.A. Sanderson,
V.R. Tolbert, D.D. Wolf, High-value renewable energy from prairie grasses, Environ. Sci. Technol. 36 (10) (2002) 2122-2129.

[10] A. Prochnow, M. Heiermann, M. Plöchl, B. Linke, C. Idler, T. Amon, P.J. Hobbs, Bioenergy from permanent grassland - a review: 1, Biogas, Bioresour. Technol. 100 (21) (2009) 4931-4944.

[11] J.D. Murphy, N.M. Power, An argument for using biomethane generated from grass as a biofuel in Ireland, Biomass Bioenergy 33 (3) (2009) 504-512.

[12] D. Massé, Y. Gilbert, P. Savoie, G. Bélanger, G. Parent, D. Babineau, Methane yield from switchgrass and reed canarygrass grown in Eastern Canada, Bioresour. Technol. 102 (22) (2011) 10286-10292.

[13] K. Pirhofer-Walzl, K. Søegaard, H. Høgh-Jensen, J. Eriksen, M.A. Sanderson, J. Rasmussen, J. Rasmussen, Forage herbs improve mineral composition of grassland herbage, Grass Forage Sci. 66 (3) (2011) 415-423.

[14] R. Wahid, L. Feng, W.-F. Cong, A.J. Ward, H.B. Møller, J. Eriksen, Anaerobic monodigestion of lucerne, grass and forbs - influence of species and cutting frequency, Biomass Bioenergy 109 (2018) 199-208.

[15] R. Wahid, A.J. Ward, H.B. Møller, K. Søegaard, J. Eriksen, Biogas potential from forbs and grass-clover mixture with the application of near infrared spectroscopy, Bioresour. Technol. 198 (2015) 124-132.

[16] H.B. Møller, S.G. Sommer, B.K. Ahring, Methane productivity of manure, straw and solid fractions of manure, Biomass Bioenergy 26 (5) (2004) 485-495.

[17] American Public Health Association - APHA, Standard Methods for the Examination of Water and Wastewater, Washington, 21th ed., (2005).

[18] P.J. Van Soest, J.B. Robertson, B.A. Lewis, Methods for dietary fiber, neutral detergent fiber, and nonstarch polysaccharides in relation to animal nutrition, J. Dairy Sci. 74 (10) (1991) 3583-3597.

[19] H.M. Lo, T.A. Kurniawan, M.E.T. Sillanpää, T.Y. Pai, C.F. Chiang, K.P. Chao, M.H. Liu, S.H. Chuang, C.J. Banks, S.C. Wang, K.C. Lin, C.Y. Lin, W.F. Liu, P.H. Cheng, C.K. Chen, H.Y. Chiu, H.Y. Wu, Modeling biogas production from organic fraction of MSW co-digested with MSWI ashes in anaerobic bioreactors, Bioresour. Technol. 101 (16) (2010) 6329-6335.

[20] A. Elgersma, K. Søegaard, S.K. Jensen, Herbage dry-matter production and forage quality of three legumes and four non-leguminous forbs grown in single-species stands, Grass Forage Sci. 69 (4) (2014) 705-716.

[21] J. Jing, K. Søegaard, W.-F. Cong, J. Eriksen, Species diversity effects on productivity, persistence and quality of multispecies swards in a four-year experiment, PLoS One 12 (1) (2017).

[22] G. Li, P.D. Kemp, Forage chicory (Cichorium intybus L.): a review of its agronomy and animal production, Adv. Agron. 88 (2005) 187-222.

[23] B. Wintsche, K. Glaser, H. Sträuber, F. Centler, J. Liebetrau, H. Harms, S. Kleinsteuber, Trace elements induce predominance among methanogenic activity in anaerobic digestion, Front. Microbiol. 7 (2016) 2034.

[24] Y. Chen, J.J. Cheng, K.S. Creamer, Inhibition of anaerobic digestion process: a review, Bioresour. Technol. 99 (10) (2008) 4044-4064.

[25] B. Demirel, P. Scherer, The roles of acetotrophic and hydrogenotrophic methanogens during anaerobic conversion of biomass to methane: a review, Rev. Environ. Sci. Biotechnol. 7 (2) (2008) 173-190.

[26] T. Liu, L. Sun, B. Müller, A. Schnürer, Importance of inoculum source and initial community structure for biogas production from agricultural substrates, Bioresour. Technol. 245 (2017) 768-777.

[27] V. Moset, N. Al-zohairi, H.B. Møller, The impact of inoculum source, inoculum to substrate ratio and sample preservation on methane potential from different substrates, Biomass Bioenergy 83 (2015) 474-482.

[28] J. Pagés-Díaz, I. Pereda-Reyes, M.J. Taherzadeh, I. Sárvári-Horváth, M. Lundin, Anaerobic co-digestion of solid slaughterhouse wastes with agro-residues: synergistic and antagonistic interactions determined in batch digestion assays, Chem. Eng. J. 245 (2014) 89-98.

[29] P.V. Rao, S.S. Baral, Experimental design of mixture for the anaerobic co-digestion of sewage sludge, Chem. Eng. J. 172 (2-3) (2011) 977-986.

[30] X. Wang, G. Yang, F. Li, Y. Feng, G. Ren, X. Han, Evaluation of two statistical methods for optimizing the feeding composition in anaerobic co-digestion: mixture design and central composite design, Bioresour. Technol. 131 (2013) 172-178.

[31] W.-F. Cong, J. Jing, J. Rasmussen, K. Søegaard, J. Eriksen, Forbs enhance productivity of unfertilised grass-clover leys and support low-carbon bioenergy, Sci. Rep. 7 (2017) 1422.

[32] B.A. Woodcock, J. Savage, J.M. Bullock, M. Nowakowski, R. Orr, J.R.B. Tallowin, R.F. Pywell, Enhancing floral resources for pollinators in productive agricultural grasslands, Biol. Conserv. 171 (2014) 44-51. 